\title{
Pengaruh Gaya Kepemimpinan Terhadap Kinerja Karyawan Deekey Shoes Garage
}

\author{
Dr. Wa Ode Zusnita Muizu, S.E., M.Si. 1) \\ waode.zusnita@unpad.ac.id \\ FEB Unpad \\ Muhammad Irfan2) \\ irfancielz@gmail.com \\ Program Studi S1 Manajemen FEB Unpad \\ Dr. Umi Kaltum, SE., MSi. \\ Umi.kaltum@gmail.com \\ FEB Unpad \\ Jl. Dipati Ukur No. 35 Bandung 40132
}

Hp: 081320668149

\begin{abstract}
Abstrak
Di era globalisasi, perusahaan dituntut untuk memperbaiki segala aspek yang terkait dalam perusahaan tersebut dan lebih responsif agar terus bertahan dan berkembang. Salah satu aspek yang harus menjadi perhatian lebih oleh perusahaan adalah sumber daya manusia. Oleh karena itu, sumber daya manusia pada setiap perusahaan menjadi sangat penting dan sulit untuk dikelola karena berhubungan dengan pembentuk sikap seseorang yang tentunya dapat berpengaruh terhadap kinerja sumber daya manusia tersebut terhadap performansi perusahaan.

Tujuan dari penelitian ini adalah untuk mengetahui pengaruh gaya kepemimpinan terhadap kinerja karyawan pada Deekey Shoes Garage. Penelitian ini didasarkan pada pentingnya pengaruh gaya kepemimpinan terhadap kinerja karyawan. Metode yang digunakan dalam penelitian ini adalah metode deskriptif dan metode verifikatif. Sampel penelitian yaitu seluruh karyawan Deekey Shoes Garage yaitu berjumlah 80 orang.

Hasil penelitian menunjukkan bahwa gaya kepemimpinan mempunyai pengaruh positif dan signifikan 5\% terhadap kinerja karyawan, dengan koefisien determinasi sebesar $69 \%$ dimana kinerja karyawan dipengaruhi olah gaya kepemimpinan. Sementara sisanya $31 \%$ dipengaruhi oleh variabel-variabel lain di luar variabel yang diteliti misalnya variabel individu (Kemampuan dan keterampinan, latar belakang pribadi dan demografis), variabel organisasi (Sumber daya, imbala, struktur dan desainpekerjaan) dan atau variabel psikologis (Persepsi, sikap, kepribadian, belajar dan motivasi).
\end{abstract}

Kata Kunci : Gaya Kepemimpinan, Kinerja Karyawan 


\section{Pendahuluan}

\subsection{Latar Belakang}

Pada era globalisasi dewasa ini, iklim persaingan antar perusahaan yang bergerak di bidang industri manufaktur maupun industri jasa semakin tinggi dan semakin kompleks. Perusahaan dituntut untuk memperbaiki segala aspek yang terkait dalam perusahaan tersebut dan lebih responsif agar terus bertahan dan berkembang. Salah satu aspek yang harus menjadi perhatian lebih oleh perusahaan adalah sumber daya manusia. Oleh karena itu, sumber daya manusia pada setiap perusahaan menjadi sangat penting dan sulit untuk dikelola karena berhubungan dengan pembentuk sikap seseorang yaitu kognitif (perseptual), afektif (emosional), dan konatif (perilaku) yang tentunya dapat berpengaruh terhadap kinerja sumber daya manusia tersebut terhadap performansi perusahaan.

Di hampir semua perusahaan yang ada, karyawan merupakan asset yang wajib mereka jaga terutama bagi perusahaan yang khususnya bergerak di bidang jasa pelayanan yang mengandalkan tingkat kinerja karyawan di perusahaannya. Oleh karena itu perusahaan dituntut untuk mampu mengoptimalkan kinerja karyawannya. Salah satu pendekatan dalam upaya meningkatkan kinerja karyawan tersebut melalui penerapan gaya kepemimpinan yang tepat oleh pemimpin perusahaan.

Menurut Hersey dan Blanchard dikutip oleh Rivai (2014) menyatakan bahwa hubungan antara pimpinan dan anggotanya mempunyai empat tahap/fase yang diperlukan bagi pimpinan untuk mengubah gaya kepemimpinan-nya yaitu: Tahap pertama, pada kesiapan awal perhatian pimpinan pada tugas sangat tinggi, anggota diberi instruksi yang jelas dan dibiasakan dengan peraturan, struktur dan prosedur kerja. Tahap kedua adalah di mana anggota sudah mampu menangani tugasnya, perhatian pada tugasnya sangat penting karena bawahan belum dapat bekerja tanpa struktur, kepercayaan pimpinan pada bawahan semakin meningkat. Tahap ketiga di mana anggota mempunyai kemampuan lebih besar dan motivasi berprestasi mulai tampak dan mereka secara aktif mencari tanggung jawab yang lebih besar, pemimpin masih harus mendukung dan memberikan perhatian, tetapi tidak perlu lagi memberikan pengarahan. Tahap keempat adalah tahap di mana anggota mulai percaya diri, dapat mengarahkan diri dan pengalaman, pemimpin dapat mengurangi jumlah perhatian dan pengarahan

Kondisi tersebut menjadi perhatian hampir semua keluhan pelaku usaha, tidak terkecuali perusahaan jasa cuci sepatu Deekey Shoes Garage. Perusahaan jasa cuci sepatu Deekey Shoes Garage, merupakan salah satu perusahaan jasa yang berada di Kota Bandung dengan total cabang maupun workshop berjumlah lima cabang. Sebagai perusahaan jasa, Deekey Shoes Garage sangat tergantung kepada kinerja karyawannya dimana kualitas pelayanan dan ketepatan waktu pelayanan menjadi faktor paling penting dalam menjalankan usaha bisnisnya

Saat ini, dari hasil obeservasi awal yang dilakukan pada Deekey Shoes Garage, terjadi permasalahan dengan realisasi tingkat pendapatan yang kurang optimal karena adanya penurunan realisasi pendapatan pada seluruh cabang Deekey Shoes Garage tersebut. Untuk lebih jelasnya, dapat dilihat dari tabel di bawah ini: 
Tabel 1.1

Target dan Realiasai Pendapatan Deekey Shoes Garage tahun 2014-2016

\begin{tabular}{c|c|c|c|c}
\hline \multirow{2}{*}{ No } & Deskripsi Data & \multicolumn{3}{|c|}{ Tahun } \\
\cline { 3 - 5 } & & $\mathbf{2 0 1 4}$ & $\mathbf{2 0 1 5}$ & $\mathbf{2 0 1 6}$ \\
\hline 1 & Asset & $\mathrm{Rp} 190.000 .000$ & $\mathrm{Rp} 220.000 .000$ & $\mathrm{Rp} 240.000 .000$ \\
\hline 2 & Target Pendapatan & $\mathrm{Rp} 180.000 .000$ & $\mathrm{Rp} 210.000 .000$ & $\mathrm{Rp} 240.000 .000$ \\
\hline 3 & Realisasi Pendapatan & $\mathrm{Rp} 165.000 .000$ & $\mathrm{Rp} 180.000 .000$ & $\mathrm{Rp} 210.000 .000$ \\
\hline 4 & Pencapain Target & $91,6 \%$ & $90 \%$ & $87,5 \%$ \\
\hline
\end{tabular}

\section{Sumber : Deekey Shoes Garage}

Berikut data keluhan pada Deekey Shoes Garage:

Tabel 1.2

Data Keluhan Konsumen Deekey Shoes Garage

\begin{tabular}{l|l|c|c|c|}
\hline \multicolumn{1}{|c|}{ INDIKATOR } & $\begin{array}{c}\text { Tahun } \\
\mathbf{2 0 1 4}\end{array}$ & $\begin{array}{c}\text { Tahun } \\
\mathbf{2 0 1 5}\end{array}$ & $\begin{array}{c}\text { Tahun } \\
\mathbf{2 0 1 6}\end{array}$ \\
\hline & KUALITAS HASIL PEKERJAAN & $\begin{array}{c}\text { Jumlah } \\
\text { Keluhan }\end{array}$ & $\begin{array}{c}\text { Jumlah } \\
\text { Keluhan }\end{array}$ & $\begin{array}{c}\text { Jumlah } \\
\text { Keluhan }\end{array}$ \\
\hline 1 & Kebersihan Sepatu & 8 kasus & 5 kasus & 2 kasus \\
\hline 2 & Warna Sepatu & 3 kasus & 6 kasus & 3 kasus \\
\hline 3 & Wangi Sepatu & - & - & - \\
\hline 4 & Jahitan Sepatu & 3 kasus & 1 kasus & 1 kasus \\
\hline 5 & Packaging Sepatu & 2 kasus & - & - \\
\hline & KETELITIAN (DETAILING) & & & \\
\hline 1 & Outsole & - & 1 kasus & 1 kasus \\
\hline 2 & Midsol & 2 kasus & - & - \\
\hline 3 & Upper & - & - & - \\
\hline 4 & Uppers & 5 kasus & 7 kasus & 2 kasus \\
\hline 5 & Trim & - & - & 1 kasus \\
\hline 6 & Laces & - & - & - \\
\hline & JESPONSIVITAS & & & \\
\hline & Sikap Terhadap Konsumen & 21 kasus & 12 kasus & 8 kasus \\
\hline 2 & Komunikasi Terhadap Konsumen & $\mathbf{4 7 ~ k a s u s ~}$ & $\mathbf{3 2 ~ k a s u s ~}$ & $\mathbf{1 9}$ kasus \\
\hline
\end{tabular}

\subsection{Identifikasi Masalah}

Berdasarkan dari uraian pada latar belakang masalah, maka dapat dirumuskan masalah di Deekey Shoes Garage adalah sebagai berikut:

1. Bagaimana gambaran gaya kepemimipinan yang diterapkan di Deekey Shoes Garage.

2. Bagaimana gambaran kinerja karyawan pada Deekey Shoes Garage.

3. Bagaimana pengaruh gaya kepemimpinan terhadap kinerja karyawan pada Deekey Shoes Garage. 


\subsection{Maksud dan Tujuan Penelitian}

Maksud dilakukannya penelitian ini adalah untuk mengumpulkan dan mengolah data mengenai gaya kepemimpinan yang berhubungan dengan kinerja karyawan.

Adapun tujuan penelitian adalah sebagai berikut:

1. Untuk mengetahui jenis gaya kepemimpinan Deekey Shoes Garage.

2. Untuk mengetahui tingkat kinerja karyawan pada Deekey Shoes Garage

3. Untuk mengetahui pengaruh gaya kepemimipinan terhadap kinerja karyawan Deekey Shoes Garage

\subsection{Kegunaan Penelitian}

Hasil penelitian ini diharapkan dapat berguna sebagai masukan dan bermanfaat bagi pihak yang berkepentingan diantaranya sebagai berikut:

1. Bagi Penulis

Hasil penelitian ini dapat digunakan untuk melatih kemampuan cara berpikir secara sistematis dan menambah wawasan serta pengetahuan mengenai manajemen sumber daya manusia khususnya gaya kepemimpinan dan kinerja

2. Bagi Akademisi

Sebagai bahan kajian dan pengembangan teori dalam disiplin ilmu manajemen sumber daya manusia, khususnya tentang gaya kepemimpinan dan kinerja karyawan . Penelitian ini juga dapat dijadikan dasar bagi peneliti lainnya yang berniat untuk meneliti mengenai permasalahan yang sama.

3. Bagi Perusahaan

Hasil penelitian ini diharapkan dapat berguna sebagai masukan dan sumbangan yang dapat digunakan pihak manajemen dan pimpinan perusahaan mengenai gaya kepemimpinan sehingga perusahaan dapat menjadi lebih baik lagi dari sebelumnya.

\section{Kajian Pustaka, Kerangka Pemikiran, dan Hipotesis}

\subsection{Kajian Pustaka}

\subsubsection{Gaya Kepmimpinan}

Salah satu aspek penting dalam menyukseskan kepemimpinan yang baik adalah melalui gaya kepemimpinan. Kepemimpinan bersifat umum, begitu juga gaya kepemimpinannya, sehingga dapat diaplikasikan kepada berbagai bidang kehidupan. Untuk mencapai tujuan yang efektif, tidak cukup mempraktikan satu gaya kepemimpinan saja. Fidler mengatakan bahwa, tidak ada seseorang yang dapat menjadi pemimpin yang berhasil dengan hanya menerapkan satu macam gaya untuk segala situasi. Pemimpin itu akan berhasil menjalankan kepemimpinannya apabila menerapkan gaya kepemimpinan yang berbeda untuk menghadapi situasi yang berbeda. (Sutarto, 2001 : 110)

Model kontingensi Fidler ini sejalan dengan gaya kepemimpinan situasional dari Hersey dan Blanchard. Konsepsi kepemimpinan situasional ini melengkapi pemimpin dengan pemahaman yang efektif dengan tingkat kematangan (maturity) pengikutnya. Perilaku pengikut atau bawahan ini amat penting untuk mengetahui kepemimpinan situasional, karena bukan saja pengikut sebagai individu bisa menerima atau menolak pemimpinnya, akan tetapi sebagai kelompok, pengikut dapat menentukan kekuatan pribadi apapun yang dimiliki pemimpin

Menurut Hersey dan Blanchard (1995 :191), terdapat empat macam gaya kepemimpinan yaitu : 
1. Gaya Mengarahkan (Telling)

Mampu memberikan pengarahan secara spesifik pada karyawan dalam mencapai tujuan perusahaan, memberikan perintah yang harus dikerjakan karyawan.

2. Gaya Melatih (Selling)

Mengikutsertakan karyawan dalam diskusi dan memberikan kesempatan karyawan untuk berkomunikasi, aktif menyimak pendapat karyawan.

3. Gaya Mendukung (Participating)

Berperan dalam memberikan dorongan pada karyawan, melibatkan karyawan dalam pemecahan masalah dan pengambilan keputusan

4. Gaya Mendelegasikan (Delegating)

Memberikan karyawan kebebasan untuk menentukan arahnya sendiri, memberikan wewenang dan tanggung jawab yang penuh pada karyawan.

Berikut model gaya kepemimpinan situasional menurut Hersey dan Blanchard :

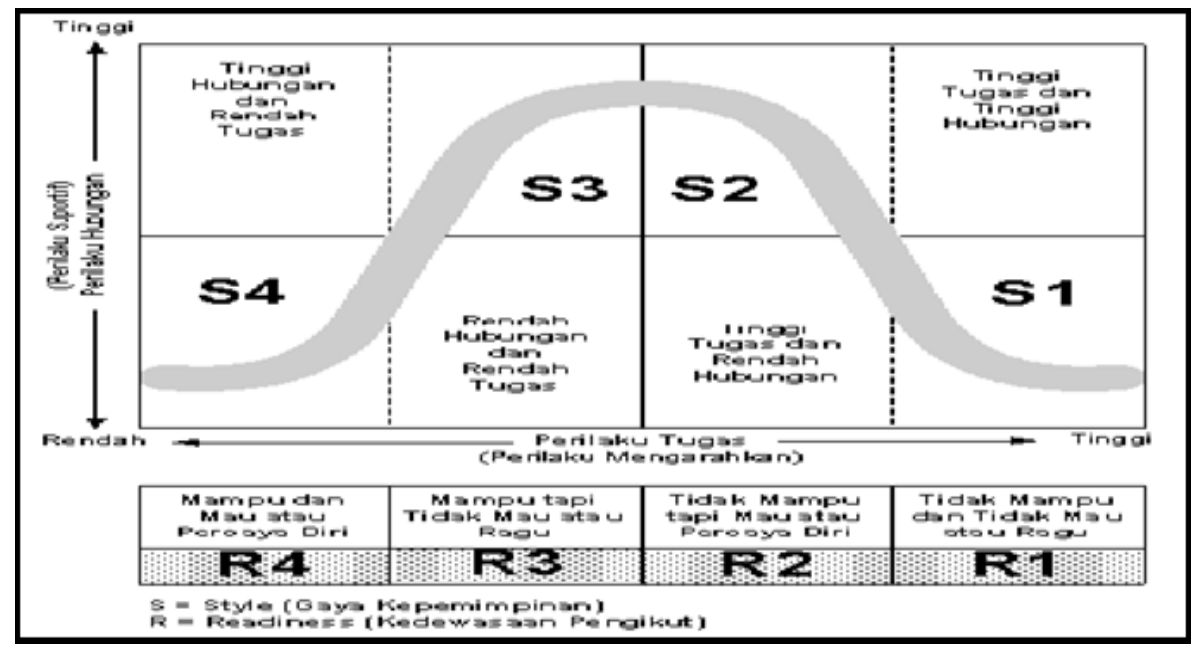

Gambar 2.1

Model Gaya Kepemimpinan Situasional

(Sumber : Gibson, 1997 : 39)

\subsubsection{Jenis-jenis Gaya Kepemimpinan}

Secara relative, ada tiga macam gaya kepemimpinan yang berbeda, yaitu otokratis, demokratis, dan laisesez-faire. Kebanyakan manager menggunakan ketiganya pada suatu waktu, tetapi gaya yang paling sering digunakan akan dapat dipakai untuk membedakan seorang manajer sebagai pemimpin yang otokratis, demokratis, atau laisesez-faire. Menurut White dan Lippit yang dikutip oleh Reksohadiprodjo dan Handoko (2001 : 298), mengemukakan tiga tipe kepemimpinan yaitu:

\section{Otokratis}

a. Semua penentuan kebijaksanaan ditentukan oleh pemimpin

b. Teknik-teknik dan langkah-langkah diatur oleh atasan setiap waktu, sehingga langkah-langkah yang akan datang selalu tidak pasti untuk tingkat yang luas.

2. Demokratis

a. Semua kebijaksanaan terjadipada kelompok diskusi dan keputusan diambildengan dorongan dan bantuan kelompok.

b. Kegiatan-kegiatan didiskusikan, langkah-langkah umum untuk tujuan kelompok dibuat dan bila dibutuhkan petunjuk-petunjuk teknis, pemimpin 


\section{Laissez-faire}

menyarankan dua atau lebih alternatif prosedur yang dapat dipilih

a. Kebebasan penuh bagi keputusan kelompok atau individu, dengan partisipasi minimal dari pemimpin

b. Bahan-bahan yang bermacam-macam disediakan oleh pemimpin yang membuat orang selalu siap bila dia memberikan informasi saat ditanya.

\subsubsection{Faktor-faktor yang Mempengaruhi Gaya Kepemimpinan}

Dalam melaksankan aktivitas pemimpin dipengaruhi oleh berbagai macam faktor. Menurut H. Jodeph Reitz yang dikutip Nanang Fattah, faktor yang mempengaruhi gaya kepemimpinan adalah sebagai berikut:

1. Kepribadian (personality). Pengalaman masala lalu dan harapan pemimpin, hal mencakup nilai-nilai, latar belakang dan pengalamannya akan mempengaruhi pilihan akan gaya kepemimpinan.

2. Harapan dan perilaku atasan.

3. Karakteristik, harapan dan perilaku bawahan mempengaruhi terhadap apa gaya kepemimpinan yang digunakan

4. Kebutuhan tugas, setiap tugas bawahan juga kan mempengaruhi gaya pemimpin

5. Iklim dan kebijakan organisasi mempengaruhi harapan dan perilaku bawahan.

6. Harapan dan perilaku rekan

\subsection{Kerangka Pemikiran}

Secara sistematik, kerangka pemikiran tersebut dapat diungkapkan dalam bagan di bawah ini :

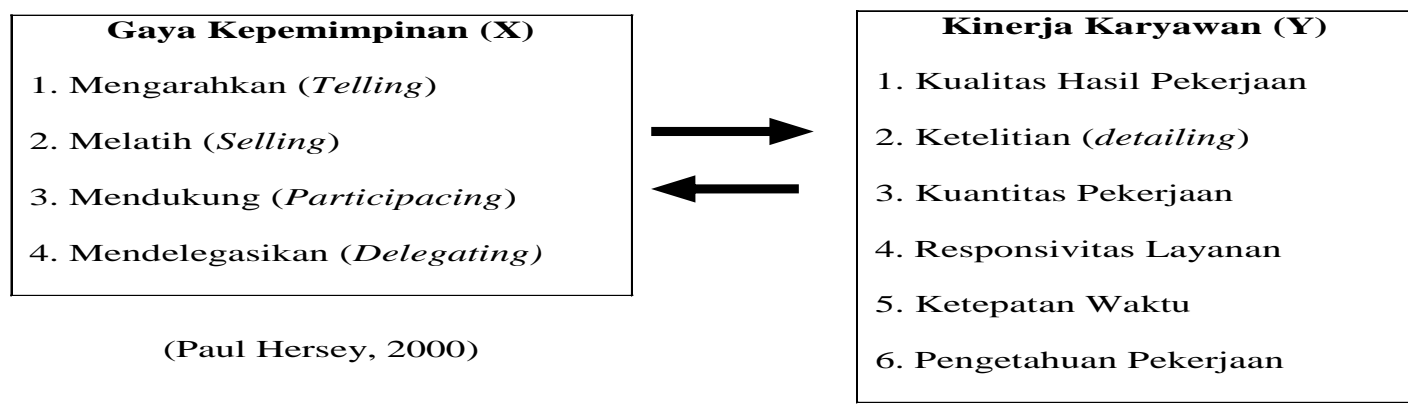

\section{Gambar 2.3 \\ Paradigma Penelitian}

\subsection{Hipotesis Penelitian}

Berdasarkan kerangka pemikiran di atas, maka dikemukan hipotesis penelitian, gaya kepemimpinan secara signifikan akan berpengaruh baik pada kinerja karyawan Deekey Shoes Garage. Berdasarkan uraian tersebut di atas maka dapat dirumuskan hipotesisnya sebagai berikut :

Ha: Gaya kepemimpinan mempunyai pengaruh secara signifikan terhadap kinerja karyawan. 


\section{Metode Penelitian}

\subsection{Metode Penlitian}

\subsubsection{Desain Penelitian}

Penelitian ini bertujuan untuk memperoleh gambaran mengenai gaya kepemimpinan dengan kinerja karyawan pada Deekey Shoes Garage Kota Bandung. Maka dari itu metode yang digunakan dalam penelitian ini adalah metode deskriptif dan metode verifikatif.

Metode deskriptif analisis merupakan penelitian untuk menemukan fakta dengan interpretasi yang tepat, serta untuk menggambarkan fenomena secara akurat, dengan tujuan menguji hipotesis-hipotesis dan mengadakan interpretasi yang lebih dalam tentang hubunganhubungan atau untuk menjawab pertanyaan yang berkaitan dengan objek yang diteliti.

Adapun metode ini bertujuan untuk memperoleh gambaran tentang parameterparameter yang diteliti dalam keadaan sekarang. Atas dasar tersebut dicarikan jawaban bagi pemecahan masalah terhadap parameter yang ada. Tipe hubungan antara variabel yang diteliti adalah hubungan kasual, dimana dalam penelitian ini, peneliti akan berusaha mengungkap hubungan sebab akibat antara variabel independen yang dalam penelitian ini adalah gaya kepemimpinan dan variabel dependen yang dalam penelitian ini adalah kinerja karyawan.

\subsubsection{Operasional Variabel}

Variabel yang di gunakan dalam penelitia terdiri dari dua variabel yaitu variabel bebas dan variabel terikat dimana variabel bebas adalah gaya kepemimpinan, dan variabel terikat adalah kinerja karyawan.

Pada tabel 3.1 ditunjukkan operasionalisasi variabel dari penelitian ini, berikut operasionalisasi variabelnya :

Tabel 3.1

Operasionalisasi variable

\begin{tabular}{|c|c|c|c|c|}
\hline bel & Konsep Variabel & Dimensi & Ukuran & Indikator \\
\hline \multirow[t]{4}{*}{ ıpinan } & \multirow[t]{4}{*}{\begin{tabular}{l}
\multicolumn{2}{l}{ Gaya } \\
kepemimpinan \\
adalah pola \\
tingkah laku, \\
kata, dan seorang \\
pemimpin yang \\
dirasakan oleh \\
orang lain (Paul \\
Hersey, 2000)
\end{tabular}} & $\begin{array}{ll}\text { 1. } & \text { Mengarah } \\
& \text { kan } \\
& \text { (Telling) }\end{array}$ & \begin{tabular}{|l|} 
a. \\
Tingkat \\
kemampuan \\
memberikan \\
pengarahan \\
secara spesifik \\
terhadap \\
karyawan dalam \\
mencapai tujuan \\
perusahaan \\
b. Tingkat \\
kemampuan \\
memberikan \\
perintah yang \\
harus dikerjakan \\
bawahan
\end{tabular} & 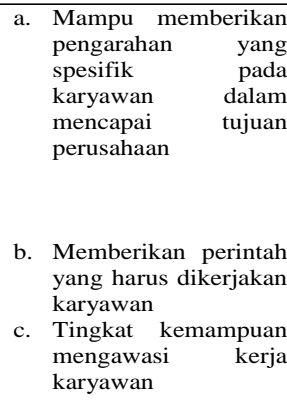 \\
\hline & & \begin{tabular}{|ll} 
2. & $\begin{array}{l}\text { Melatih } \\
\text { (Selling) }\end{array}$
\end{tabular} & \begin{tabular}{|ll} 
a. & Tingkat \\
& mengikutsertaka \\
$\mathrm{n}$ karyawan \\
dalam diskusi \\
dan memberikan \\
kesempatan \\
karyawan untuk \\
berkomunikasi \\
b. \\
Tingkat \\
keaktifan dalam \\
menyimak \\
pendapat \\
karyawan
\end{tabular} & $\begin{array}{ll}\text { a. } & \text { Mengikutsertakan } \\
\text { karyawan dalam } \\
\text { diskusi memberikan } \\
\text { kesempatan karyawan } \\
\text { untuk berkomunikasi }\end{array}$ \\
\hline & & $\begin{array}{ll}\text { 3. } & \text { Menduku } \\
& \text { ng } \\
& \text { (Participa } \\
& \text { ting) }\end{array}$ & \begin{tabular}{|ll} 
a. & Tingkat peranan \\
& dalam \\
& memberikan \\
& dorongan \\
& terhadap \\
& karyawan \\
b. & Tingkat \\
& keterlibatan \\
& karyawan dalam \\
pemecahan \\
masalah dan \\
pengambilan \\
keputusan
\end{tabular} & $\begin{array}{ll}\text { a. } & \begin{array}{l}\text { Berperan dalam } \\
\text { memberikan } \\
\text { dorongan } \\
\text { karyawan }\end{array} \\
\text { b. } & \begin{array}{l}\text { Melibatkan karaywan } \\
\text { dalam pemecahan }\end{array} \\
& \begin{array}{l}\text { masalah dan } \\
\text { pengambilan } \\
\text { keputusan }\end{array}\end{array}$ \\
\hline & & 4. Mendeleg & a. Tingkat & a. Memberikan \\
\hline
\end{tabular}




\begin{tabular}{|c|c|c|c|c|}
\hline \multirow[t]{6}{*}{$1(Y)$} & \multirow{6}{*}{$\begin{array}{l}\text { Kinerja } \\
\text { merupakan } \\
\text { pekerjaan efektif } \\
\text { dan } \\
\text { dengan } \\
\text { mempertimbangk } \\
\text { an data seseorang } \\
\text { mengenai tingkat } \\
\text { kecerobohan, turn } \\
\text { over, kehadiran, } \\
\text { dan } \\
\text { keterlambatan. } \\
\text { (Cenzo, 1999) }\end{array}$} & $\begin{array}{ll}\text { 1. } & \text { Kualitas } \\
\text { Kerja }\end{array}$ & $\begin{array}{l}\text { a. Penyelesaiaan } \\
\text { b. Kemampuan }\end{array}$ & $\begin{array}{l}\text { a. Tingkat penyelesaian } \\
\text { pekerjaan } \\
\text { b. Tingkat kemampuan } \\
\text { dalam menyelesaikan } \\
\text { pekerjaan }\end{array}$ \\
\hline & & 2. Ketelitian & $\begin{array}{l}\text { Penyelesaian yang } \\
\text { sesuai }\end{array}$ & $\begin{array}{l}\text { Tingkat } \\
\text { pengerjaan }\end{array}$ \\
\hline & & $\begin{array}{ll}\text { 3. } & \text { Responsiv } \\
\text { itas } \\
\text { Layanan } \\
\end{array}$ & $\begin{array}{l}\text { Responsivitas } \\
\text { terhadap pelayanan } \\
\text { kepada konsumen }\end{array}$ & $\begin{array}{lr}\text { Tingkat } & \text { kemampuan } \\
\text { karyawan dalam } \\
\text { melayani konsumen }\end{array}$ \\
\hline & & $\begin{array}{l}\text { 4. Ketepatan } \\
\text { Waktu }\end{array}$ & $\begin{array}{l}\text { Penyelesaian yang } \\
\text { sesuai }\end{array}$ & $\begin{array}{l}\text { Tingkat ketepatan waktu } \\
\text { penyelesaian }\end{array}$ \\
\hline & & $\begin{array}{ll}\text { 5. } & \text { Kuantitas } \\
\text { Kerja }\end{array}$ & $\begin{array}{l}\text { Volume } \\
\text { pekerjaan }\end{array}$ & $\begin{array}{lcr}\text { Tingkat } & \text { volume } & \text { hasil } \\
\text { pekerjaan } & \text { dalam } & \text { waktu } \\
\text { normal } & & \\
\end{array}$ \\
\hline & & $\begin{array}{l}\text { 6. Pengetahu } \\
\text { an } \\
\text { Pekerjaan }\end{array}$ & $\begin{array}{l}\text { Cara melaksanakan } \\
\text { pekerjaan }\end{array}$ & $\begin{array}{l}\text { Tingkat pengetahuan dan } \\
\text { pelaksanaan pekerjaan }\end{array}$ \\
\hline
\end{tabular}

\subsubsection{Populasi dan Sampel Penelitian}

Populasi menurut Sugiyono (2010) adalah wilayah generalisasi yang terdiri atas subyek yang mempunyai kualitas dan karakteristik tertentu yang ditetapkan oleh peneliti untuk dipelajari dan kemudian ditarik kesimpulannya. Populasi dalam penelitian ini adalah seluruh karyawan dari Deekey Shoes Garage yang berjumlah 80 orang. Karena tenaga kerja yang masih relative tidak terlalu banyak, maka populasi akan diambil seluruhnya untuk dijadikan sebagai sampel penelitian.

\subsubsection{Teknik Pengumpulan Data}

Teknik pengumpulan data yang dilakukan adalah sebagai berikut :

1. Penentuan Lapangan (Field Research)

Dilakukan secara langsugn kepada karyawan yang bersangkutan dengan mengumpulkan dan mencatat data, fakta dan informasi untuk mendapatkan gambaran tentang perusahaan.
a. Wawancara
b. Observasi.
c. Penyebaran angket (Kuesioner)
d. Studi kepustakaan (Library Research)

Tabel 3.2

Pembobotan Skala Likert

\begin{tabular}{|l|c|c|}
\hline \multicolumn{1}{|c|}{ Pilihan Jawaban } & $\begin{array}{c}\text { Skor Pernyataan } \\
\text { Positif }\end{array}$ & $\begin{array}{c}\text { Skor Pernyataan } \\
\text { Negatif }\end{array}$ \\
\hline Sangat Setuju & 5 & 2 \\
\hline Setuju & 4 & 3 \\
\hline Ragu-ragu & 3 & 4 \\
\hline Tidak Setuju & 2 & 5 \\
\hline Sangat Tidak Setuju & 1 & \\
\hline
\end{tabular}




\subsubsection{Uji Validitas dan Reliabilitas}

Uji reliabilitas dimaksudkan untuk mengukur suatu kuesioner yang merupakan indikator dari variabel. Reabilitas diukur dengan uji statistik cronbach's alpha $(\alpha)$. Suatu variabel dikatakan reliabel jika memberikan nilai cronbach's alpha $>0,60$.

Uji validitas digunakan untuk mengukur sah atau valid tidaknya suatu kuesioner. Uji validitas dilakukan dengan melakukan korelasi bivariate antara masing-masing skor indikator dengan total skor variabel.

\subsubsection{Teknik Analisis Data}

Untuk membuktikan hipotesis yang telah dikemukakan maka dalam penelitian ini digunakan:

1. Analisis Kualitatif Deskriptif

2. Analisis Kuntitatif

Dimana regresinya adalah :

$$
Y=a+\beta X
$$

$\mathrm{Y}=$ Subyek dalam variabel dependen yang diprediksikan dalam hal ini kinerja karyawan

$\mathrm{a}=$ Harga $\mathrm{Y}$ bila $\mathrm{X}=0$ (harga konstan)

$\beta=$ Angka arah atau koefisien regresi, yang menunjukkan angka peningkatan ataupun penurunan variabel independen. Bila b (+) maka naik, dan bila (-) maka terjadi penurunan.

$\mathrm{X} 1$ = Variabel independen, yaitu Gaya Kepemimpinan

\subsubsection{Pengujian Hipotesis}

\section{a. Uji T (Uji Parsial)}

Uji ini digunakan untuk mengetahui apakah masing-masing variabel bebasnya secara sendiri-sendiri berpengaruh secara signifikan terhadap variabel terikatnya. Dengan rumus hipotesis sebagai berikut :

Ho : $\beta=0$, gaya kepemimpinan tidak mempunyai pengaruh signifikan terhadap kinerja karyawan.

Ha $: \beta \neq 0$, gaya kepemimpinan mempunyai pengaruh signifikan terhadap kinerja karyawan.

Dilakukannya uji $\mathrm{t}$ adalah untuk menunjukkan apakah terdapat signifikansi tertentu pada tingkat probabilitas yang ditetapkan. Dalam penelitian ini dilakukan uji t satu posisi positif dan negatif.

Apabila $t$ hitung $\leq+\mathrm{t}$ tabel maka Ho tidak dapat ditolak

Apabila $t$ hitung $>+t$ tabel maka Ho dapat ditolak

\subsubsection{Analisis Koefisien Determinasi}

Pada model regresi linier sederhana ini, akan dilihat besarnya kontribusi untuk variabel bebas terhadap variabel terikatnya dengan melihat besarnya koefisien determinasi totalnya (R2). Jika (R2) yang diperoleh mendekati 1 (satu) maka dapat dikatakan semakin kuat model tersebut menerangkan hubungan variabel bebas terhadap variabel terikat. Sebaliknya jika (R2) makin mendekati 0 (nol) maka semakin lemah pengaruh variabel terhadap variabel terikat. 


\section{Hasil Penelitian dan Pembahasan}

\subsection{Analisis Deskriptif Data Penelitian}

Data penelitian ini merupakan hasil jawaban responden dalam mengisi kuesioner penelitian yang disebarkan. Pada analisa penelitian, diuraikan berdasarkan operasionalisasi variabel penelitian untuk menjawab identifikasi masalah.

Teknik analisis statistik deskriptif bertujuan untuk menjelaskan keseluruhan data yang dikumpulkan dengan memaparkan, mengelompokkan, dan mengklasifikasikan ke dalam tabel distribusi frekuensi yang kemudian diberikan penjelasan.

\subsubsection{Karakteristik Responden}

Penelitian dilakukan dengan menyebar kuesioner kepada karyawan Deekey Shoes Garage sebagai responden. Kuesioner telah disebar oleh peneliti sebanyak 80 buah. Hasil penelitian yang dilakukan kepada 80 responden tersebut memperlihatkan adanya karakteristik reponden yang bervariasai, yaitu dari segi jenis kelamin, usia, dan lama berkerja.

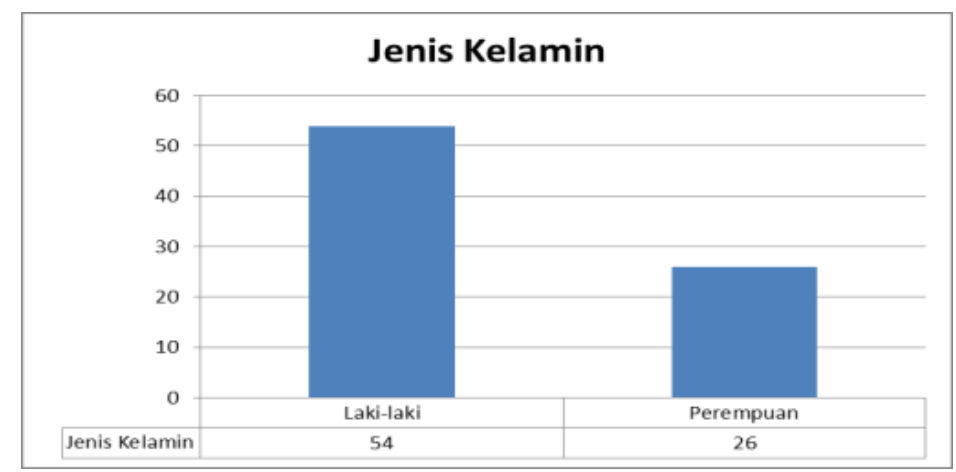

Gambar 4.1

Karakteristik Berdasarkan Jenis Kelamin

Sumber: Data primer yang diolah, 2017

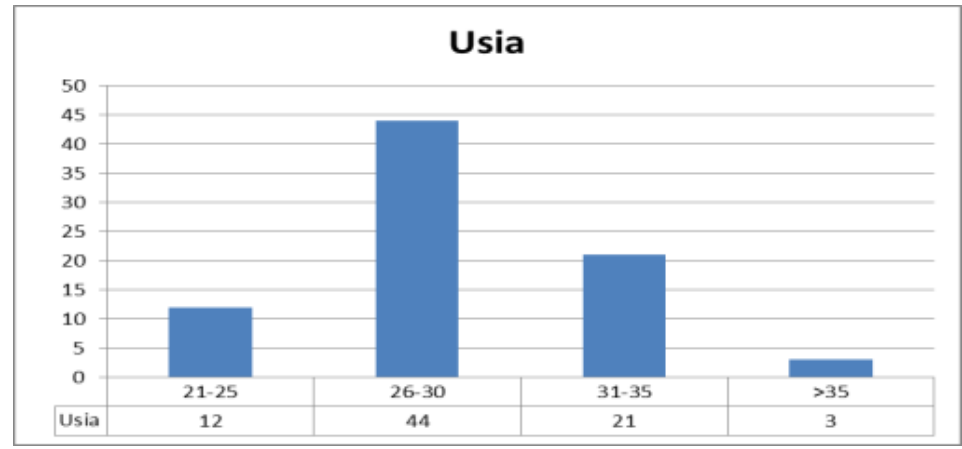

Gambar 4.2

Karakteristik Berdasarkan Usia

Sumber: Data primer yang diolah, 2017 


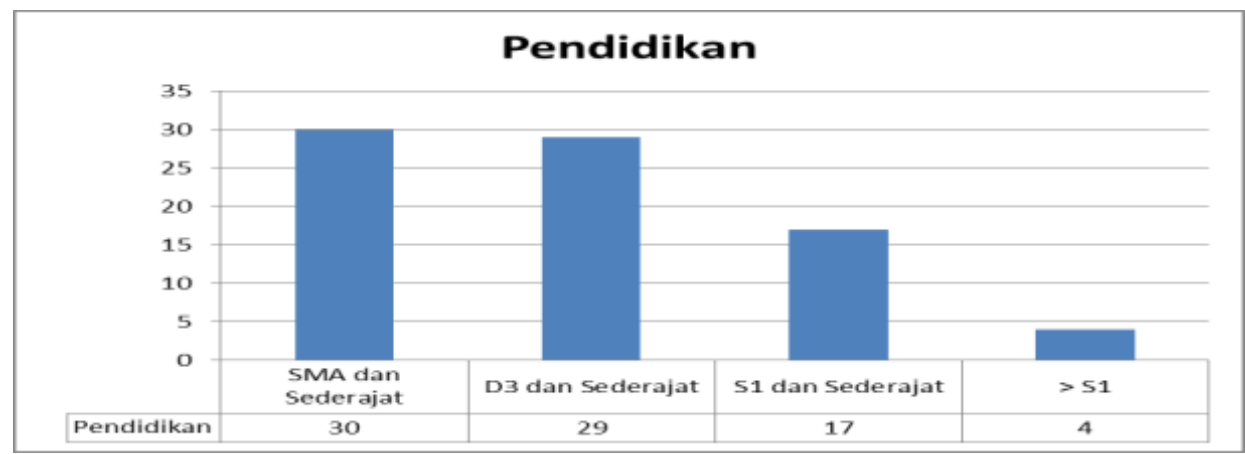

Gambar 4.3

Karakteristik Berdasarkan Pendidikan

Sumber: Data primer yang diolah, 2017

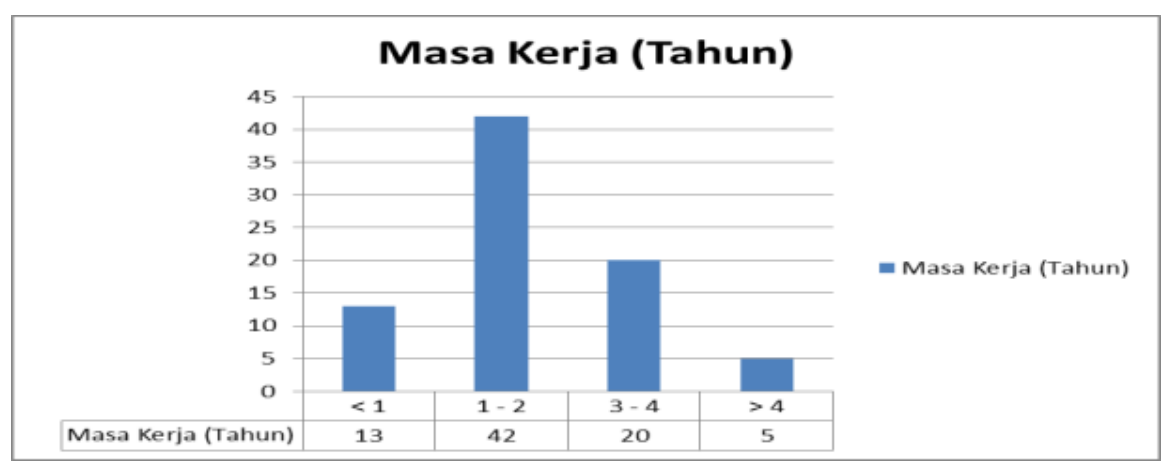

Gambar 4.4

Karakteristik Berdasarkan Masa Kerja

Sumber: Data primer yang diolah, 2017

\subsubsection{Gaya Kepemimpinan pada Deekey Shoes Garage}

Secara detail, kondisi tersebut dapat dijelaskan melalui penyajian sebaran jawaban dari 80 responden untuk item-item pertanyaan variabel Gaya Kepemimpinan di bawah ini.

\section{Tabel 4.1}

Atasan memberikan pengarahan yang spesifik dan jelas dalam pekerjaan

\begin{tabular}{|c|c|c|c|c|}
\hline $\begin{array}{c}\text { Tanggapan } \\
\text { Responden }\end{array}$ & Bobot & Frekuensi & Persentase & $\begin{array}{c}\text { Bobot } \mathbf{x} \\
\text { Frekuensi }\end{array}$ \\
\hline Sangat Setuju & 5 & 2 & $0,25 \%$ & 10 \\
\hline Setuju & 4 & 23 & $28,75 \%$ & 92 \\
\hline Kurang Setuju & 3 & 30 & $37,5 \%$ & 90 \\
\hline Tidak Setuju & 2 & 25 & $31,25 \%$ & 50 \\
\hline $\begin{array}{c}\text { Sangat Tidak } \\
\text { Setuju }\end{array}$ & 1 & 0 & $0 \%$ & 0 \\
\hline TOTAL & & 80 & $100 \%$ & 242 \\
\hline
\end{tabular}




$\begin{array}{ll}\text { Nilai indeks minimum } & =\text { skor minimal } \times \text { banyak responden } \\ \text { Nilai indeks maksimum } & =1 \times 80=80 \\ & =\text { skor maksimal } \times \text { banyak responden } \\ \text { Interval } & =5 \times 80=400 \\ & =\text { indeks maksimum }- \text { indeks minimum } \\ & =400-80=320 \\ \text { Jarak interval } & =\text { interval }: \text { jenjang } \\ & =320: 5=64\end{array}$

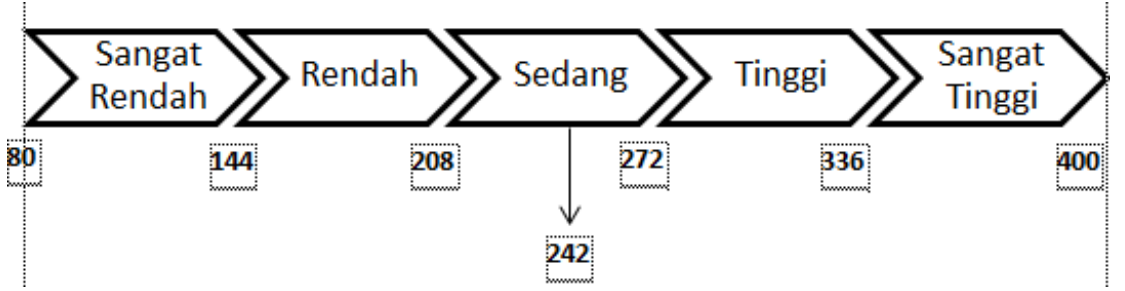

Gambar 4.6

Atasan memberikan pengarahan yang spesifik dan jelas dalam pekerjaan

Dari tabel dan gambar di atas dapat diketahui bahwa tanggapan responden mengenai pernyaataan "Atasan memberikan pengarahan yang spesifik dan jelas dalam mencapai tujuan perusahaan". Mayoritas pegawai menjawab kurang setuju yaitu sebanyak 30 orang atau 37,5\% hal ini menjelaskan bahwa tingkat pengarahan atau instruksi di Deekey Shoes Garage masih sedang. Hasil temuan di lapangan menunjukan bahwa, setiap pekerjaan yang dilakukan oleh Deekey Shes Garage memerlukan perlakukaan yang berbeda sehingga setiap masing-masing pekerjaan mempunyai spesifikasi cara pengerjaan yang berbeda pula, contohnya adalah cara mencuci sepatu berbahan suede berbeda dengan cara mencuci sepatu berbahan canvas sehingga para pekerja harus mempunyai pemahaman yang baik. Maka dari itu, tingkat pengarahan atau instruksi di Deekey Shoes Garage harus lebih ditingkatkan guna mencegah terjadinya kesalahan dalam melakukan pekerjaan.

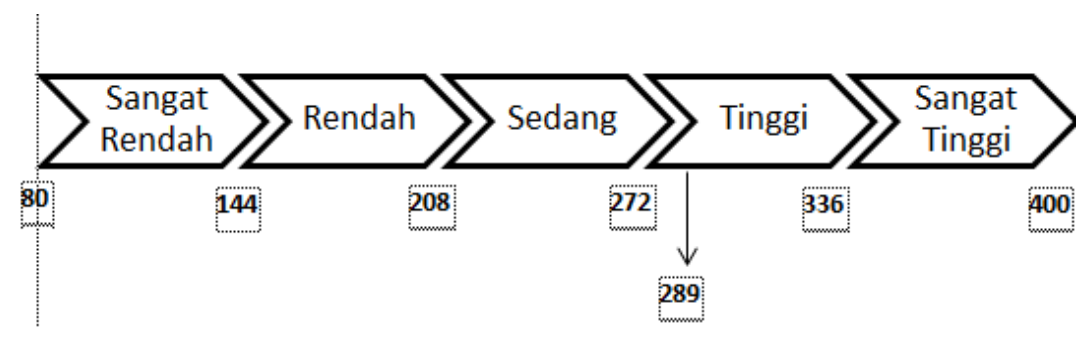

Gambar 4.7

Atasan memberi kesempatan berdiskusi mengenai pekerjaan

Dari gambar di atas dapat diketahui bahwa tanggapan responden mengenai pernyaataan "Atasan sering mengajak diskusi mengenai pekerjaan". Mayoritas pegawai menjawab kurang setuju yaitu sebanyak 33 orang atau $41,25 \%$ namun terdapat 40 orang atau $50 \%$ yang menjawab setuju dan sangat setuju, hal ini menjelaskan bahwa tingkat komunikasi antara atasan dengan pegawai di Deekey Shoes Garage sudah tinggi namun tetap harus ditingkatkan dengan mengajak diskusi ke seluruh pegawai agar informasi terbaru mengenai pekerjaan baik itu bersifat teknis maupun non teknis dapat tersampaikan dan dipahami oleh seluruh pegawai sehingga dapat meningkatkan performansi perusahaan. Temuan di lapangan menunjukan, atasan selalu melakukn sharing atau diskusi mengenai pekerjaan baik itu bersifat teknis maupun non teknis. Salah satu contohnya adalah apabila ada cara atau treatment baru 
dalam menghilangkan noda bandel pada sepatu maupun tas yang lebih efisien dan optimal, atasan selalu memberi tahu pada pekerja sebagai cara untuk meningkatkan performansi perusahaan, begitu pua sebaliknya, jika pekerja menemukan cara atau treatment baru, atasan mempersilahkan cara tersebut untuk diaplikasikan pada sepatu maupun tas asalkan masih sesuai SOP perusahaan dan tentunya harus lebih efisien dan lebih optimal dari cara lama.

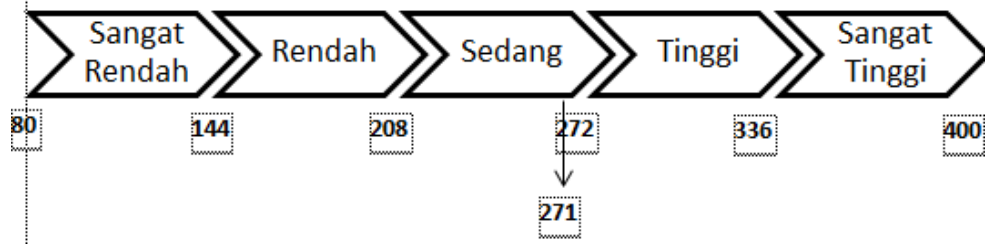

Gambar 4.8

Atasan memberikan bantuan dan masukan jika Anda menemukan kesulitan dalam menyelesaikan tugas

Dari gambar di atas dapat diketahui bahwa tanggapan responden mengenai pernyaataan "Atasan memberikan bantuan dan masukan jika Anda menemukan kesulitan dalam menyelesaikan tugas". Mayoritas pegawai menjawab setuju yaitu sebanyak 29 orang atau $36,25 \%$, namun yang menjawan kurang setuju dan tidak setuju adalah sebanyak 42 orang, hal ini menjelaskan bahwa tingkat partisipasi atasan di Deekey Shoes Garage sudah sedang dan cukup baik namun atasan harus lebih menyeluruh memberikan perhatian ke setiap pegawai. Hasil temuan di lapangan menunjukan, atasan cukup baik dalam memberikan problem solving kepada para pekerja yang mengalami kesulitan. Contohnya, ketika pekerja megalami kesulitan ketika warna sepatu menjadi kusam karena beberapa faktor seperti kualitas sepatu yang KW atau replika, atasan memberikan solusi dengan memerintahkn pekerja untuk melakukan repaint atau cat ulang dengan tidak membebankan biaya repint pada pekerja. Hal ini karena terkadang pekerja sulit membedakan antara sepatu asli dengan sepatu replika.

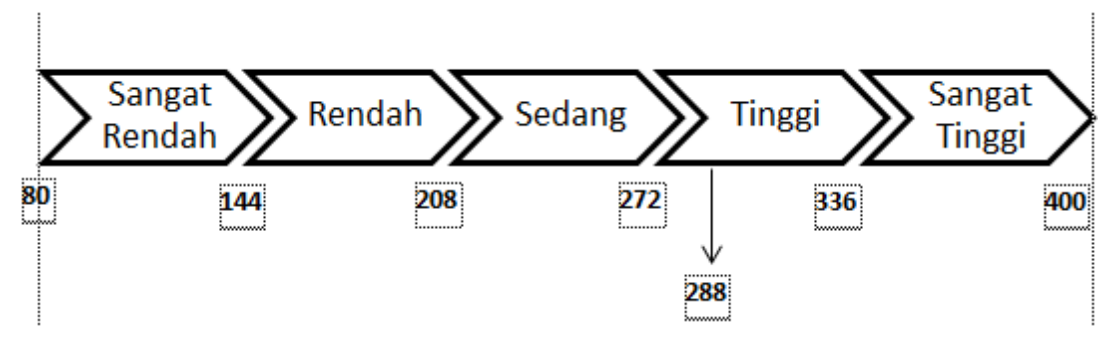

Gambar 4.9

Atasan memberikan punish dan reward kepada anda dan pegawai lainnya

Dari gambar di atas dapat diketahui bahwa tanggapan responden mengenai pernyaataan "Atasan memberikan punish dan reward kepada anda dan pegawai lainnya". Mayoritas pegawai menjawab setuju yaitu sebanyak 41 orang atau $51,25 \%$ hal ini menjelaskan bahwa penerapan untuk memotivasi pegawai agar selalu mengerjakan pekerjaan dengan baik dan benar oleh atasan Deekey Shoes Garage dikategorikan tinggi dan sudah baik. Hasil temuan di lapangan menunjukan, atasan selalu memberika punish dan reward kepada setiap pekerja yang melakukan pekerjaan dengan sangat baik diatas standar yang ditentukan perusahaan. Contohnya, target setiap pekerja untuk mencuci sepatu adalah 100 sepatu setiap bulan, apabila melebihi target, atasan selalu memberikan bonus baik berupa uang tunai 
maupun dalam bentuk lain dengan catatan tidak ada komplain dari pelanggan terhadap hasil sepatu yang dikerjakan.

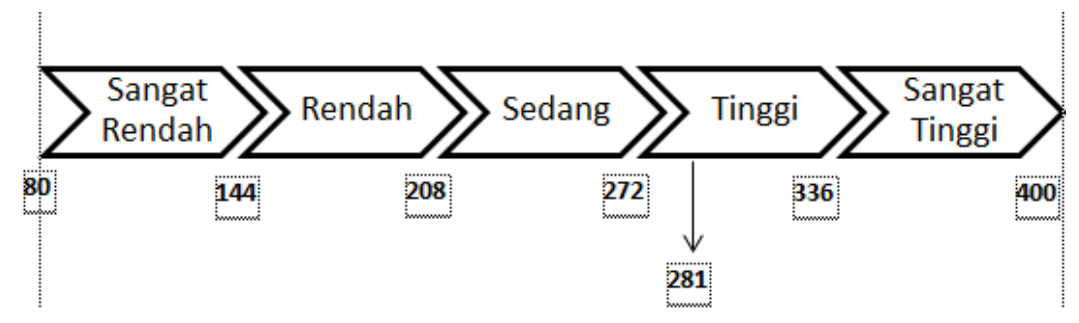

Gambar 4.10

Atasan aktif menyimak pendapat dan keluhan pegawai

Dari gambar di atas dapat diketahui bahwa tanggapan responden mengenai pernyaataan "Atasan aktif menyimak pendapat dan keluhan pegawai". Mayoritas pegawai menjawab kurang setuju yaitu sebanyak 38 orang atau $47,5 \%$ hal ini menjelaskan bahwa ketersediaan atasan Deekey Shoes Garage untuk mendengarkan pendapat dan keluhan pegawainya dikategorikan tinggi dan sudah baik. Hasil temuan di lapangan menunjukan, atasan sangat terbuka dan responsif terhadap pendapat dan keluhan pekerja. Contohnya, ketika pekerja terdapat keluhan dan ingin menyampaikannya, atasan selalu mempersilahkan dengan cara membuat forum setiap akhir pekan kepada para pekerja yang ingin menyampaikan keluhan.

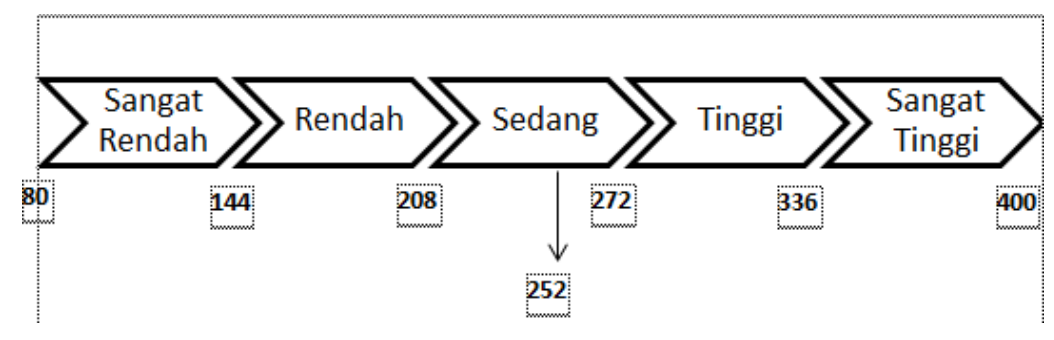

Gambar 4.11

Atasan memberikan evaluasi hasil kerja pegawai

Dari gambar di atas dapat diketahui bahwa tanggapan responden mengenai pernyaataan "Atasan memberikan evaluasi hasil kerja pegawai". Mayoritas pegawai menjawab tidak setuju yaitu sebanyak 26 orang atau $32,5 \%$ hal ini menjelaskan bahwa atasan di Deekey Shoes Garage memiliki kecenderungan sedang dalam mengevaluasi hasil kerja pegawainya. Hasil temuan di lapangan menunjukan, karena kesibukan atasan di luar Deekey Shoes Garage berimbas pada evaluasi yang sedang atau jarang terhadap hasil kerja pegawainya. Contohnya adalah evaluasi dilakukan ketika terdapat komplain mengenai hasil pekerjaan dari pelanggan. Hal ini karena, atasan sangat mempercayai pegawainya dalam melakukan pekerjaan. 


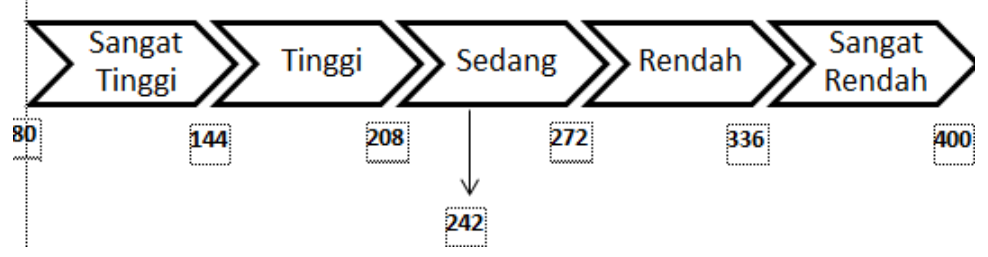

Gambar 4.12

Atasan tidak pernah melakukan pengawasan terhadap pegawainya dalam menyelesaikan tugas

Dari tabel dan gambar di atas dapat diketahui bahwa tanggapan responden mengenai pernyaataan "Atasan tidak pernah melakukan pengawasan terhadap pegawainya dalam menyelesaikan tugas". Mayoritas pegawai menjawab kurang setuju yaitu sebanyak 30 orang atau 37,5\% hal ini menjelaskan bahwa atasan Deekey Shoes Garage dalam hal mengawasi pekerjaan pegawainya dikategorikan sedang dan atau cukup baik. Hasil temuan di lapangan menunjukan, dalam melakukan pengawasan, atasan tidak terlalu mencolok dalam mengawasi hasil pekerjaan yang dilakukan pegawainya. Contohnya adalah ketika pegawai selesai melakukan pekerjaannya, atasan hanya menanyakan apakah hasilnya maksimal atau tidak, tanpa memeriksa secara detail hasil pekerjaan pegawainya.

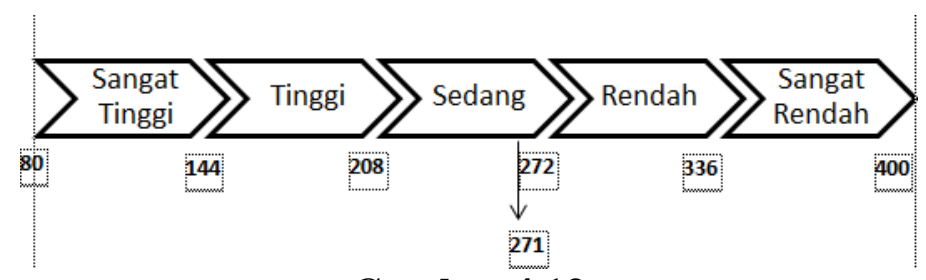

Gambar 4.13

\section{Atasan tidak pernah memeriksa tugas pegawai, sebelum pegawai meminta feedback}

Dari tabel dan gambar di atas dapat diketahui bahwa tanggapan responden mengenai pernyaataan "Atasan tidak pernah memeriksa tugas pegawai, sebelum pegawai meminta feedback". Mayoritas pegawai menjawab tidak setuju yaitu sebanyak 33 orang atau 41,25\% hal ini menjelaskan bahwa tingkat kontrol pegawai oleh atasan Deekey Shoes Garage sedang atau sudah cukup baik namun perlu diperhatikan kembali bahwa kontrol pegawai yang sudah dilakukan belum dirasakan oleh sebagian pegawai jika dilihat dari responden yang menyatakan setuju dan kurang setuju mencapai 48,75\%. Hasil temuan di lapangan menunjukan, kemungkinan atasan memeriksa hasil pekerjaan pegawainya bersifat sedang yang artinya, atasan hanya memeriksa ketika pegawainya meminta untuk diperiksa, namun bukan berarti ataan tidak pernah memeriksa hasil pekerjaan pegawainya. Terkadang atasan melakukan inspeksi mendadak terhadap hasil pekerjaan pegawainya.

Dari poin-poin pernyataan diatas mengenai Gaya Kepemimpinan dapat diketahui ternyata item pernyataan yang memiliki nilai paling tinggi adalah "Atasan memberi kesempatan berdiskusi mengenai pekerjaan", pernyataan tersebut terdapat di dimensi melatih (Selling), dengan indikator mengikutsertakan karyawan dalam diskusi memberikan kesempatan karyawan untuk berkomunikasi. Diskusi adalah visi dari dua atau lebih individu yang berinteraksi secara verbal dan dengan saling bertatap muka tentang tujuan atau target yang telah diberikan dengan cara pertukaran informasi atau mempertahankan. Sehingga dengan adanya atau banyaknya diskusi tersebut diharapkan dapat mempercepat dan mempermudah pekerjaan. 


\subsubsection{Kinerja Karyawan pada Deekey Shoes Garage}

Untuk mengetahui hasil penelitian yang berkaitan dengan Kinerja Karyawan (Y), maka dilakukan dengan menghitung jumlah sebaran kuesioner jawaban responden penelitian atas item pernyataan Kinerja Karyawan.

Hasil skor tanggapan responden untuk variabel Gaya Kepemimpinan sebesar 1570. Skor maksimum jawaban responden adalah $5 \times 80 \times 6=2400$ dan skor minimum jawaban responden adalah $1 \times 80 \times 6=480$. Sehingga dari hasil skor tersebut diperoleh nilai interval sebesar $(2400-480): 5=384$

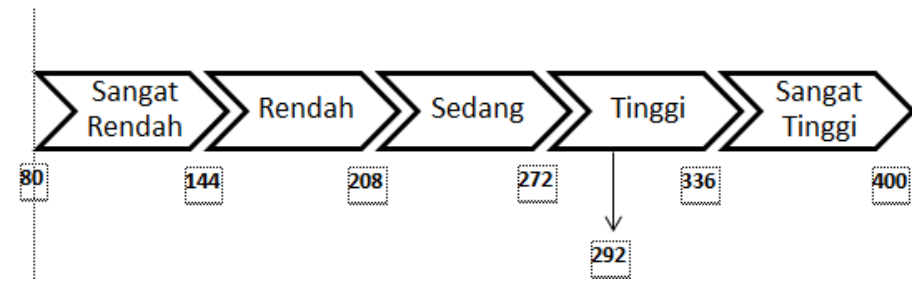

Gambar 4.15

\section{Rekan kerja saya bekerja sesuai dengan prosedur kerja yang telah ditentukan}

Dari gambar di atas dapat diketahui bahwa tanggapan responden mengenai pernyaataan "Rekan kerja saya bekerja sesuai dengan prosedur kerja yang telah ditentukan". Mayoritas pegawai menjawab setuju yaitu sebanyak 42 orang atau $52,25 \%$ hal ini menjelaskan bahwa tingkat ketepatan hasil pekerjaan yang dikerjakan pegawai di Deekey Shoes Garage dikategorikan tinggi dan sudah baik. Hasil temuan di lapangan menunjukan, setiap pagawai sudah melakukan peerjaan sesuai SOP dengan baik. Contohnya adalah setiap sepatu maupun tas sudah dilakukan treatment sesuai dengan bahan, jenis, dan kualitas sepatu maupun tas tersebut.

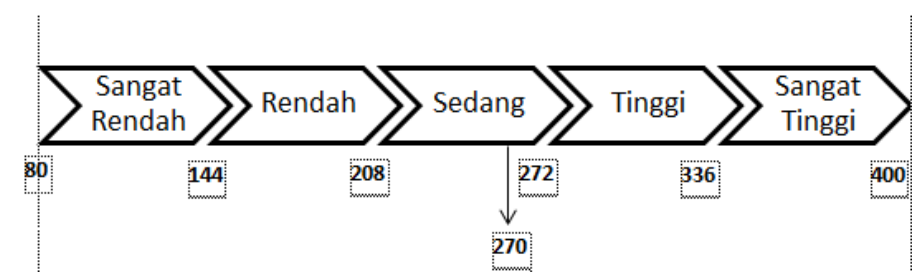

Gambar 4.16

Rekan kerja saya mengetahui cara menyelesaikan tugas

Dari gambar di atas dapat diketahui bahwa tanggapan responden mengenai pernyaataan "Rekan kerja saya mengetahui cara menyelesaikan tugas". Mayoritas pegawai menjawab setuju yaitu sebanyak 31 orang atau 38,75\% hal ini menjelaskan bahwa tingkat job knowledge pegawai di Deekey Shoes Garage dapat dikatakan sedang dan cukup baik namun diperlukan beberapa pelatihan untuk beberapa pegawai yang belum memiliki job knowledge yang baik. Hasil temuan di lapangan menunjukan, terkadang pegawai menanyakan kepada pegawai lainnya apabila mengalami kesulitan. Contohnya adalah ketika pegawai A mengalami kendala dalam cara mengeringkan sepatu berbahan kulit imitasi, pegawai tersebut bertanya pada pegawai lainnya yang lebih senior apakah cara mengeringkan sepatu berbahan tersebut harus menggunakan mesin pengering atau dijemur di bawah sinar matahari. Hal ini biasanya terjadi apabila atasan tidak ada di workshop sehingga sering antar pegawai melakukan sharing dengan pegawai lainnya. 


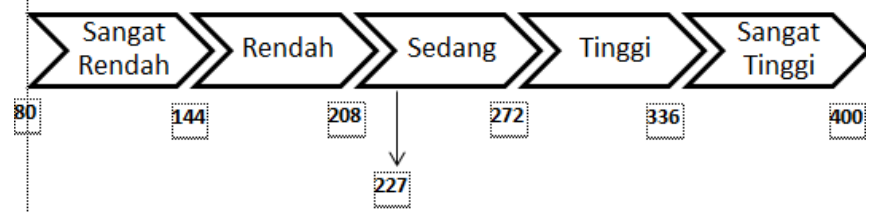

Gambar 4.17

\section{Rekan kerja saya dapat menyelesaikan tugas dengan tepat waktu}

Dari gambar di atas dapat diketahui bahwa tanggapan responden mengenai pernyaataan "Rekan kerja saya dapat menyelesaikan tugas dengan tepat waktu". Mayoritas pegawai menjawab tidak setuju yaitu sebanyak 38 orang atau $47,5 \%$ hal ini menjelaskan bahwa tingkat volume hasil kerja dalam waktu normal yang yang dimiliki oleh pegawai Deekey Shoes Garage dikategorikan sedang menuju rendah sehingga diperlukan perhatian pimpinan agar kuantitas pekerjaan para pegawainya menjadi lebih baik. Hasil temuan di lapangan menunjukan, masih terjadinya pekerjaan yang tidak selesai dengan tepat waktu misalnya pegawai outlet-outlet Deekey Shoes Garage yang terlambat dalam memberikan sepatu dan tas kepada workshop sehingga meperlambat kinerja workshop Deekey Shoes Garage.

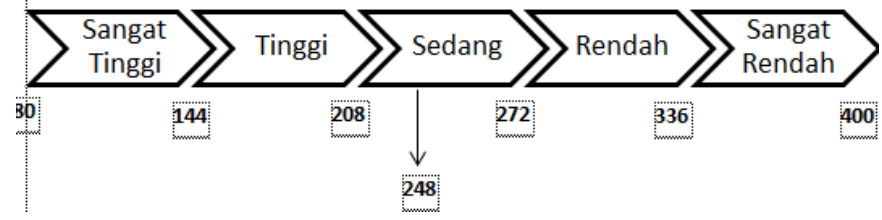

Gambar 4.18

Rekan kerja saya mengalami keterlambatan dalam menyelesaikan tugas

Dari gambar di atas dapat diketahui bahwa tanggapan responden mengenai pernyaataan "Rekan kerja saya mengalami keterlambatan dalam menyelesaikan tugas". Mayoritas pegawai menjawab setuju yaitu sebanyak 28 orang atau 35\% dan 51 orang pegawai menjawab kurang setuju, tidak setuju dan sangat tidak setuju hal ini menjelaskan bahwa tingkat penyelesaian pekerjaan pegawai di Deekey Shoes Garage dikategorikan sedang dan cukup baik namun tetap harus diperhatikan. Hasil temuan di lapangan menunjukan, masih terjadinya keterlambatan walaupun relatif rendah seperti keterlambatan dalam menyelesaikan pekerjaan sesuai yang dijanjikan kepada pelanggan. Contohnya adalah, cuci sepatu dengan treatment Premium yang secara SOP selesai dengan waktu 3 hari, pekerjaan ternyata selesai dengan 4 hari. Hal ini tentu berpengaruh pada kuantitas performansi perusahaan dan kepercayaan konsumen walaupun banyak faktor yang mempengaruhi keterlambatan tersebut seperti cuaca dan loading sepatu maupun tas yang cukup tinggi.

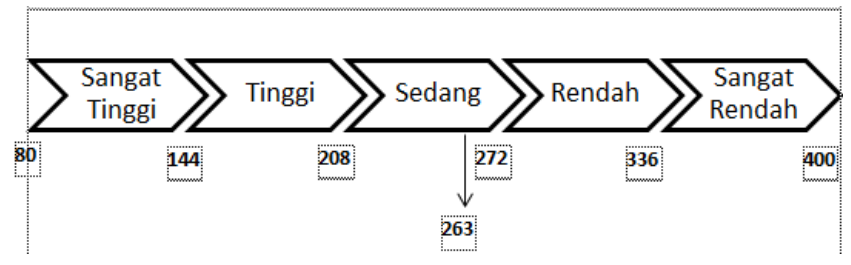

Gambar 4.19

Rekan kerja saya mengabaikan perintah atasan

Dari gambar di atas dapat diketahui bahwa tanggapan responden mengenai pernyaataan "Rekan kerja saya mengabaikan perintah atasan". Mayoritas pegawai menjawab 
kurang setuju yaitu sebanyak 31 orang atau $38,75 \%$ lalu 20 orang pegawai menjawab tidak setuju dan 11 orang pegawai menjawab sangat tidak setuju hal ini menjelaskan bahwa tingkat pegawai dalam mengikuti perintah atasan dikategorikan sedang dan cukup baik. Hasil temuan di lapangan menunjukan, peneliti tidak menemukan adanya pegawai yang tidak menuruti perintah atasan. Ketika atasan memerintahkan sesuatu terhadap pegawai, maka pada saat itu juga pegawai langsung mengerjakan apa yang diperintahkan.

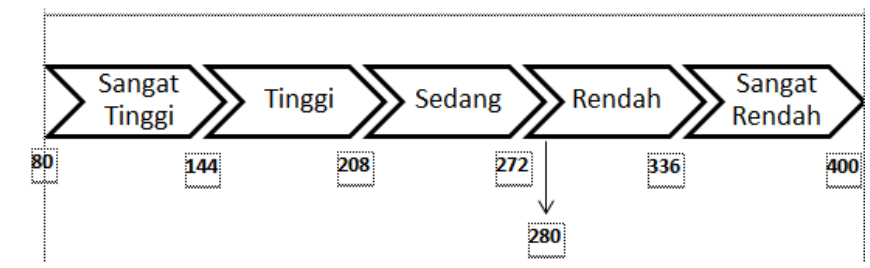

Gambar 4.20

\section{Rekan kerja saya melanggar peraturan perusahaan}

Dari tabel di atas dapat diketahui bahwa tanggapan responden mengenai pernyaataan "Rekan kerja saya melanggar peraturan perusahaan". Mayoritas pegawai menjawab kurang setuju dan tidak setuju yaitu sebanyak 29 orang dan 28 hal ini menjelaskan bahwa kepatuhan pegawai Deekey Shoes Garage dikategorikan tinggi dan sudah baik. Hasil temuan di lapangan menunjukan, tidak ditemukannya pegawai yang melakukan pelanggaran yang berdampak signifikan terhadap performansi perusahaan.

Dari poin-poin pernyataan diatas mengenai Kinerja Karyawan dapat diketahui ternyata item pernyataan yang memiliki nilai paling tinggi adalah "Rekan kerja saya bekerja sesuai dengan prosedur kerja yang telah ditentukan", pernyataan tersebut terdapat di dimensi pengetahuan pekerjaan dengan indikator Tingkat pengetahuan dan pelaksanaan pekerjaan.

\subsection{Hasil Pengujian Data Analisis Pengaruh Gaya Kepemimpinan (X) Terhadap Kinerja Karyawan (Y)}

Pada bagian hasil pengujian data, penyusun melakukan pengujian atas data kuisioner yang telah diperoleh. Pengujian data mencakup uji validitas dan uji reliabilitas dengan tujuan agar penulis tidak mengambil kesimpulan yang keliru mengenai gambaran keadaan yang sebenarnya terjadi. Pengujian validitas dan reliabilitas ini dilakukan dengan menggunakan bantuan Microsoft office Excel 2015 dan SPSS 20.0 For Windows.

\subsubsection{Hasil Uji Validitas}

Berikut hasil uji validitas Gaya Kepemimpinan (X) di Deekey Shoes Garage Kota Bandung.

Tabel 4.15

Uji Validitas Gaya Kepemimpinan

\begin{tabular}{|c|c|c|c|}
\hline $\begin{array}{c}\mathbf{N} \\
\mathbf{o}\end{array}$ & r Hitung & r Kritis & $\begin{array}{c}\text { Kesimpula } \\
\mathbf{n}\end{array}$ \\
\hline $\mathbf{1}$ & & & \\
\hline 2 & 0,418 & 0,2 & Valid \\
\hline 3 & 0,536 & 0,2 & Valid \\
\hline 4 & 0,422 & 0,2 & Valid \\
\hline 5 & 0,615 & 0,2 & Valid \\
\hline 6 & 0,503 & 0,2 & Valid \\
\hline
\end{tabular}




\begin{tabular}{|l|l|l|l|}
\hline 7 & 0,418 & 0,2 & Valid \\
\hline 8 & 0,477 & 0,2 & Valid \\
\hline
\end{tabular}

Sumber: Data Diolah

Berikut hasil uji validitas terhadap Kinerja Karyawan (Y) pada Deekey Shoes Garage.

Tabel 4.16

Uji Validitas Kinerja Karyawan

\begin{tabular}{|c|c|c|c|}
\hline No. & r Hitung & r Kritis & Kesimpulan \\
\hline 1 & 0,401 & 0,2 & Valid \\
\hline 2 & 0,716 & 0,2 & Valid \\
\hline 3 & 0,435 & 0,2 & Valid \\
\hline 4 & 0,526 & 0,2 & Valid \\
\hline 5 & 0,699 & 0,2 & Valid \\
\hline 6 & 0,670 & 0,2 & Valid \\
\hline
\end{tabular}

Sumber: Data Diolah

Berdasarkan tabel tersebut dapat diketahui bahwa pernyataan pada variabel dampak gaya kepemimpinan (X) dan kinerja karyawan (Y) seluruhnya valid. Jika $r$ korelasi pada masing-masing pernyataan lebih besar dari nilai titik kritisnya yaitu 0,2, maka dapat disimpulkan bahwa item-item tersebut valid, dalam artian item-item yang digunakan untuk mengukur variabel gaya kepemimpinan dan kinerja karyawan dalam penelitian ini mampu menghasilkan data yang akurat sesuai dengan tujuan penelitian.

\subsubsection{Hasil Uji Reliabilitas}

Metode pengukain reliabilitas adalah dengan menggunakan metode Alpha Cronbach, Standar yang digunakan dalam menentukan reliabel atau tidaknya suatu instrument penelitian umumnya adalah perbandingan antara nilai rhitung dengan rtabel pada taraf kepercayaan 95\% atau tingkat signifikansi 5\%. Apabila dilakukan pengujian reliabilitas dengan metode Alpha Cronbach, maka nilai rhitung diwaliki oleh nilai Alpha. Apabila alpha hitung lebih besar daripada rtabel dan Alpha hitung bernilai positif, maka suatu instrumen penelitian dapat disebut reliabel. Dikatakan reliabel apabila memiliki alpha lebih besar dari rtabel Product Moment untuk $\mathrm{N}=80$ dengan taraf signifikan 5\%.

Nilai dari Alpha adalah 0,849 dan nilai dari $r$ tabel adalah 0,2. Kesimpulannya Alpha $=$ $0,849>$ rtabel $=0,2$ artinya item-item kuesioner penelitian ini dapat dikatakan reliabel atau terpercaya sebagai pengumpul data dalam penelitian.

\subsubsection{Analisis Persamaan Regresi Linier Sederhana}

Tujuan digunakannya analisis regresi linier sederhana adalah untuk menaksir berapa nilai variabel Y (Kinerja Karyawan) apabila nilai variabel X (Gaya Kepemimpinan) diketahui. Dari tabel 4.17 diketahui bawah nilai koefisien constant B adalah sebesar 13,870 dan nilai koefisien variabel X (Gaya Kepemimpinan) adalah 0,207. Jadi dapat diketahui persamaan regresi variabel adalah sebagai berikut :

$$
\mathrm{Y}=13,870+0,207 \mathrm{X}
$$


Dimana :

$\mathrm{Y}=$ Kinerja Karyawan

$\mathrm{X}=$ Gaya Kepemimpinan

Dari persamaan di atas dapat diartikan bahwa setiap kenaikan variabel X (Gaya Kepemimpinan) sebesar 1 maka akan berpengaruh kepada kenaikan variabel Y (Kinerja Pegawai) sebesar 0,207 dan Variabel Y (Kinerja Karyawan) akan bernilai 13,870 ketika variabel $\mathrm{X}$ bernilai 0 .

\subsubsection{Uji Hipotesis} sebagai :

Hipotesis penelitian gaya kepemimpinan terhadap kinerja karyawan dinyatakan Ho : $\beta=0$, gaya kepemimpinan tidak mempunyai pengaruh signifikan terhadap kinerja karyawan.

$\mathrm{Ha}: \beta \neq 0$, gaya kepemimpinan mempunyai pengaruh signifikan terhadap kinerja karyawan.

Untuk menguji hipotesis model regresi tersebut dengan menggunakan aplikasi SPSS digunakan suatu teknik analisis yang hasilnya disajikan dalam tabel berikut ini :

Tabel 4.17

Hasil Analisis Regresi

\begin{tabular}{|c|c|c|c|c|c|c|}
\hline \multicolumn{7}{|c|}{ Coefficients $^{\mathrm{a}}$} \\
\hline \multirow[t]{2}{*}{ Mode } & & \multicolumn{2}{|c|}{ Unstandardized Coefficients } & \multirow{2}{*}{$\begin{array}{c}\begin{array}{c}\text { Standardized } \\
\text { Coefficients }\end{array} \\
\text { Beta }\end{array}$} & \multirow[t]{2}{*}{$t$} & \multirow[t]{2}{*}{ Sig. } \\
\hline & & B & Std. Error & & & \\
\hline \multirow{2}{*}{1} & (Constant) & 13,078 & 2,076 & & 6,299 & 000 \\
\hline & Gaya Kepemimpinan & 207 & .086 & .262 & 2,402 & .019 \\
\hline
\end{tabular}

Sumber: Data primer yang diolah, 2017

Berdasarkan perhitungan tabel tersebut diketahui nilai t hitung adalah sebesar 2,402 sedangkan $\mathrm{t}$ tabel dengan tingkat signifikansi sebesar 5\% dan dengan derajat kebebasan 80-1 $=79$ sehingga diperoleh nilai kritis distribusi t sebesar ttabel $=1,9$. Karena thitung $=2,402$ $>$ ttabel $=1,9$ atau nilai signifikansinya lebih kecil dari taraf nayata penelitian (Sig. $=0,019<$ $\alpha=0,05$ ), maka Ho tidak dapat diterima, artinya gaya kepemimpinan mempunyai pengaruh signifikan terhadap kinerja karyawan.Dengan kata lain, semakin baik gaya kepemimppinan seorang pemimpin akan semakin baik pula kinerja karyawan yang dipimpinnya.

Kepemimpinan berarti kemampuan untuk mempengaruhi,menggerakkan,dan mengarahkan suatu tindakan pada diri seseorang atau sekelompok orang untuk tujuan tertentu. Dalam upaya mempengaruhi tersebut seorang pemimpin menerapkan gaya yang berbeda beda dalam setiap situasi. Kepemimpinan yang diperankan dengan baik oleh seorang pemimpin mampu memotivasi karyawan untuk bekerja lebih baik, hal ini akan membuat karyawan lebih hati-hati dalam berusaha mencapai target yang diharapkan perusahaan, hal tersebut berdampak pada kinerjanya. 


\subsubsection{Analisis Koefisien Determinasi}

Besarnya keeratan hubungan antara gaya kepemimpinan dan kinerja karyawan ditunjukkan oleh nilai korelasi (r), sedangkan besarnya pengaruh ditunjukkan oleh koefisien determinasi $(r 2)$, sebagaimana terlihat dalam tabel di bawah ini :

Tabel 4.18

Koefisien Determinasi

\begin{tabular}{|l|r|r|r|c|}
\hline Model & $R$ & $R$ Square & $\begin{array}{c}\text { Adjusted R } \\
\text { Square }\end{array}$ & $\begin{array}{c}\text { Std. Error of the } \\
\text { Estimate }\end{array}$ \\
\hline 1 &, $863^{\mathrm{a}}$ &, 690 &, 057 & 2,27585 \\
\hline
\end{tabular}

a. Predictors: (Constant), Gaya_Kepemimpinan

Sumber: Sumber: Data primer yang diolah, 2017

Tabel diatas menjelaskan besarnya pengaruh variabel bebas terhadap variabel terikatnya. Nilai $\mathrm{R}=0,863$ dan $\mathrm{R}$ Square $=0,690$ menunjukkan bahwa 0,690 atau 69\% dimana kinerja karyawan dipengaruhi olah gaya kepemimpinan. Sementara sisanya $31 \%$ dipengaruhi oleh variabel-variabel lain di luar variabel yang diteliti misalnya variabel individu (Kemampuan dan keterampinan,

latar belakang pribadi dan demografis), variabel organisasi (Sumber daya, imbala, struktur dan desainpekerjaan) dan atau variabel psikologis (Persepsi, sikap, kepribadian, belajar dan motivasi).

\section{Kesimpulan dan Saran}

\subsection{Kesimpulan}

Berdasarkan hasil analisis data dan pembahasan yang telah dilakukan, maka dapat diambil kesimpulan sebagai berikut :

1. Gaya Kepemimpinan di Deekey Shoes Garage berada pada kategori cukup baik. Hal ini tergambar dari hasil evaluasi peneliti yang dimulai dari pengarahan dari atasan, kesempatan berdiskusi dengan atasan, bantuan dan masukkan dari atasan, punish dan reward dari atasan, keaktifan atasan dalam menyimak, evaluasi dari atasan, pengawasan oleh atasan, pemeriksaan pekerjaan oleh atasan. Gaya kepemimpinan yang paling menonjol di Deekey Shoes Garage adalah pada item "atasan memberi kesempatan berdiskui mengenai pekerjaan", pernyataan tersebut terdapat pada dimensi gaya kepemimpinan melatih (selling) dengan nilai total (bobot $\mathrm{x}$ frekuensi) sebesar 289 dari 33 orang atau 41,25\% menjawab kurang setuju dan 40 orang tau 50\% menjawab setuju. Gaya tersebut muncul karena atasan Deekey Shoes Garage selalu mengikutsertakan pegawainya dalam diskusi dan memberikan kesempatan karyawan untuk berkomunikasi dan aktif menyimak pendapat karyawan. Sedangkan untuk dimensi gaya kepemimpinan mengarahkan (telling) dengan nilai total (bobot $\mathrm{x}$ frekuensi) sebesar 242 dari 30 orang atau 37,5\% terdapat pada item pernyataan "atasan memberikan pengarahan yang spesifik dan jelas dalam pekerjaan". Untuk dimensi gaya kepemimpinan mendukung (participating) dengan nilai total (bobot $\mathrm{x}$ frekuensi) sebesar 271 dari 29 orang atau 36,25\% menjawab setuju terdapat pada item pernyataan "atasan memberikan bantuan dan masukan jika Anda menemukn kesulitan dalam menyelesaikan tugas". Sedangkan untuk dimensi gaya kepemimpinan yang terakhir 
yaitu gaya kepemimpinan mendelegsikan (delegating) mempunyai nilai total (bobot $\mathrm{x}$ frekuensi) sebesar 281 dari 28 orang atau 47,5\% menjawab kurang setuju terdapat pada item pernyataan "atasan aktif menyimak pendapat dan keluhan pegawai".

2. Kinerja Karyawan di Deekey Shoes Garage berada pada kategori cukup baik. Hal ini tergambar dari evaluasi peneliti yang dimulai dari karyawan melakukan pekerjaan sesuai SOP yaitu pekerjaan harus mengutamakan kualitas dan tepat waktu. Selain itu, karyawan mengetahui cara menyelesaikan tugas, karyawan menyelesaikan tugas dengan tepat waktu, ada atau tidaknya keterlambatan karyawan dalam menyelesaikan tugas, karyawan mengabaikan perintah atasan, dan karyawan melanggar peraturan perusahaan masih tergolong ktegori cukup baik namun masih harus perlu ditingkatkan lagi.

3. Berdasarkan hasil pengujian statistik, didapatkan hasil bahwa pada penelitian ini variabel gaya kepemimmpinan berpengaruh positif dan signifikan terhadap variabel kinerja karyawan di Deekey Shoes Garage dengan t hitung sebesar 2,402 dan nilai $t$ tabel sebesar 1,9.

\subsection{Saran}

1. Bagi Akademisi

Berdasarkan hasil penelitian ini maka dapat diambil saran sebagai berikut :

Penelitian selanjutnya disarankan untuk menambah variabel independen yang akan diteliti. Variabel independen lain yang bisa digunakan dalam penelitian selanjutnya, seperti : lingkungan kerja, motivasi kerja, tingkat kesejahteraan, tingkat disiplin, dan lain-lain.

2. Bagi Perusahaan

Pimpinan haruslah individu yang memahami betul peran, posisi dan tanggungjawab perusahaan. Selain berorientasi pada tugas, pemimpin juga harus mampu memfasilitasi kebutuhan karyawan dan mampumenjalin relasi yang baik dengan bawahan. Hal tersebut disebabkan karena karyawanpun akan mengembangkan penilaian positif atau negatif terhadap gaya kepemimpinan yang nantinya akan berdampak pada kinerjanya secara keseluruhan.

\section{Daftar Pustaka}

Adair, John, 2008. Kepemimpinan yang Memotivasi. Penerbit PT. Gramedia Pustaka Utama: Jakarta.

AM. Kadarman, 1996, Pengantar Ilmu Manajemen, PT. Gramedia Pustaka Utama, Jakarta.

Decenzo, Davis A., dan Stephen P. Robbins. 1999. Human Resource Development, Sixth Edition. USA: John Willey \& Sons Inc.

Erlangga John J. Macionis. (2008). Society the basics. United States of America: Prentice Hall.

Gibson, James .L. 1997. Manajemen. Alih bahasa Zuhad Ichyandin : Ed 9. Erlangga: Jakarta.

Hersey, Paul dan Ken Blanchard, 1995, Manajemen Perilaku Organisasi, Pendayagunaan Sumber Daya Manusia, Penerjemah: Agus Dharma. Erlangga: Jakarta.

Hersey, Paul dan Kenneth. H. Blanchard. 2000. Manajemen Perilaku Organisasi : Pendayagunaan Sumber Daya Manusia, Terjemahan Agus Dharma. Erlangga: Jakarta.

Mankunegara, Anwar Prabu 2005. Sumber Daya Manusia perusahaan. Remaja Rosdakarya: Bandung

Siagian, Sondang P. 2004. Manajemen Sumber Daya Manusia. Bumi Aksara: Jakarta.

Sugiyono. 2010. Metode Penelitian Kuantitatif Kulitatif \& RND. Alfabeta : Bandung. 
Sugiyono. 2012. Memahami Penelitian Kualitatif. Alfabeta: Bandung.

Sutarto. 2001. Dasar-dasar Organisasi, Gadjah Mada University Press, Yogyakarta.

T. Hani, Handoko dan Reksohadiprodjo, 2001, Manajemen Sumber Daya Manusia dan Perusahaan, Edisi Kedua, BPFE, Yogyakarta.

Umar, Husein. 2011. Metode Penelitian Untuk Skripsi dan Tesis Bisnis Edisi 11. PT Raja Grafindo Persada: Jakarta.

Timpe, D.A. 2000. Sari Manaejmen Sumber Daya Manusia : Produktivitas. Edisi 5 Alih Bahasa: Dimas Samudra. PT Gramedia: Jakarta.

Widyatmini, dan Luqman Hakim. 2008. Hubungan Kepemimpinan, Kompensasi, dan Kompetensi Terhadap Kinerja Karyawan Dinas Kesehatan Kota Depok. Jurnal Ekonomi Bisnis No.2 Vol.13. Hal: 163-170 